\title{
Формування мотивації школярів до занять фізичною культурою та спортом у закладах загальної середньої освіти
}

\section{Ірина Матвієнко}

Івано-Франківський коледж фрізичної культури Національного університету фрізичного виховання і спорту України, Івано-Франківськ, Україна

Анотація. На сьогодні залишається недостатньо висвітленим механізм залучення учнівської молоді до позаурочних та позашкільних фрорм фрізичного виховання, зацікавленість до занять спортом у системі дитячо-юнацького та масового спорту, що сприятиме підвищенню їх мотивації до фрізичних вправ на уроках фізичної культури. Мета. Вивчити вмотивованість школярів до відвідування уроків фізичної культури та спортивних секцій та вплив учителів фізичної культури, тренерів і батьків на формування інтересу до занять руховою активністю. Методи. Аналіз літературних джерел та мережі Інтернет, узагальнення, систематизація, методи математичної статистики. Результати. Визначено зниження інтересу школярів до занять фізичними вправами, відвідування обов'язкових фрорм занять фізичною культурою в школі, що, в свою чергу, виявляється і у відвідуванні спортивних секцій. Відповіді опитаних школярів свідчать про бажання відвідувати уроки фрізичної культури, лише незначна їх частина відвідує спортивні секції, переважна частина не займається спортом.

У ході дослідження виявлено зацікавленість учнів та батьків у заняттях на базі школи. Зміст проведення вільного часу школярів, за даними опитування, свідчить про природну потребу дітей у руховій активності та інтерес до фізичних вправ. Не сформовано мотивацію до систематичних занять руховою активністю. Доведено необхідність формування дієвого механізму організації рухової активності школярів та підвищення їх мотивації шляхом урахування інтересів у навчальний та позанавчальний час, налагодження співпраці зі спортивними клубами, ДЮСШ, визначення чітких критеріїв оцінювання мотивації до занять фізичною культурою та різними видами рухової активності і заходів до її підвищення.

Ключові слова: мотивація, рухова активність, фрізична культура, урок, спортивні секції.

\section{Iryna Matviienko}

\section{FORMATION OF MOTIVATION OF SCHOOL CHILDREN TO PRACTICING PHYSICAL CULTURE AND SPORT IN GENERAL SECONDARY EDUCATION INSTITUTIONS}

Abstract. Today, the mechanism of involving student youth in extracurricular forms of physical education, interest in sports engagement in the system of children and youth and mass sports, which will increase their motivation for exercise in physical education classes, remains insufficiently covered. Objective. To study the motivation of school children to attend physical education classes and sports sections and the influence of physical education teachers, coaches and parents on the formation of interest in practicing motor activity. Methods. Analysis of literature sources and the Internet, generalization, systematization, methods of mathematical statistics. Results. There is a decrease in the interest of school children in performing physical exercises, attending mandatory forms of physical education at school, which, in turn, is manifested in attending sports sections. The answers of the surveyed school children indicate a desire to attend physical education classes, only a small part of them attend sports sections, the vast majority are not engaged in sports. The study revealed the interest of school children and parents in classes at the school. The content of spending free time, according to the survey, indicates the natural need of children for physical activity and interest in exercise. Motivation for regular physical activity is not formed. The necessity of forming an effective mechanism for organizing motor activity of schoolchildren and increasing their motivation by taking into account interests in school and extracurricular time, establishing cooperation with sports clubs, CYSS, defining clear criteria for assessing motivation to exercise and various types of physical activity and measures to improve it has been proved.

Keywords: motivation, motor activity, physical culture, lesson, sports sections.

Matviienko I. Formation of motivation of school children to practicing physical culture and sport in general secondary education institutions. Theory and Methods of Physical education and sports. 2020; 3: 81-85 DOI: 10.32652/tmfvs.2020.3.81-85 Матвієнко І. Формування мотивації
Вступ. Фізичні вправи як один з потужних засобів здатні цілеспрямовано впливати на розвиток фоункцій і систем організму людини. Їх виконання $€$ основою зміцнення здоров'я й фрізичної підготовленості дітей. В умовах сьогодення європейські країни визнають важливість фрізичного виховання в школі. Предмет «Фізична культура» $€$ складовою навчальних планів і обов'язковим у початковій і середній школі у всіх країнах Європи, де розглядають фрізичну активність і спорт як важливий спосіб організації дозвілля підростаючого покоління [16].

у рекомендаціях B003 «Global Strategy on Diet, Physical Activity and Health» [8, 19] зазначено, що рухова активність дітей та підлітків 5-17 років повинна становити не менше однієї години на день. Звернено увагу на користь для здоров'я щоденної рухової активності понад 60 хв. А заняття фітнесом, спортом 3 високою інтенсивністю рекомендовано проводити мінімум тричі на тиждень.

У рекомендаціях «Європейської Комісії ЄС щодо рухової активності» підкреслюється значущість фрізичного виховання як обов'язкового предмета в школах більшості країн, на уроках фрізичного виховання ставиться завдання формування зацікавленості до занять фрізичними вправами. Фізичне виховання на базі школи $є$ ефективним засобом для підвищення рівня фрізичної активності та фрізичної підготовленості дітей і підлітків. Проте, як зазначено в публікації, «фрізична активність лише двічі-тричі на тиждень (за рахунок уроків фрізичної культури) сприяє незначним позитивним змінам у рівні здоров'я та підготовленості школярів» [21].

На думку Т. Круцевич [5], актуальним $є$ формування мотивації у дітей ще у шкільному віці, спрямовану на забезпечення фрізичної активності протягом життя як складової його 
здорового способу. Мотивацію підлітків до занять спортом та ефективність шкільного процесу вчені пов'язують насамперед 3 кваліфікацією та досвідом учителів [3]. Врахування принципу потребово-мотиваційного підходу вчителем фрізичної культури, на думку деяких учених [6], формує позитивне ставлення до процесу фрізичного виховання не тільки в урочний, а й у позаурочний час. Значний вплив на розвиток інтересів до навчання школярів має саме осередок за спільними інтересами занять у спортивній секції [5]. Спільні захоплення улюбленим видом спорту можуть викликати симпатію в процесі двосторонньої комунікації, підсилюючи інтерес учнівської молоді і до фрізичних вправ загалом [4].

Питання організації та методики фрізичного виховання в Україні й за кордоном цікавлять багатьох вітчизняних науковців $[5,12,20]$. Вплив мотиваційних складових на підвищення ефективності занять із фрізичної культури висвітлено у працях Г. Безверхньої, 0. Бойко, 0. Остапенко [1, 2, 7]. Удосконалення змісту навчального матеріалу з фрізичної культури, зокрема, навчальних програм для учнів 1-11-х класів, стало предметом дослідження ряду фахівців $[2,5,6,16]$. Особливе місце в дослідженнях цього напряму посідає питання залучення дітей до занять спортом, визначення їх здібностей та перспективності, залучення до масового та дитячо-юнацького спорту шляхом формування мотивації до занять руховою активністю [10, 11, 13-15]. Важлива роль сімейного виховання як необхідної передумови формування інтересу школярів до фрізичних вправ та здорового способу життя розглядається в працях 0. Жданової [4]. Разом 3 тим залишається недостатньо висвітленим механізм залучення учнівської молоді до позаурочних та позашкільних форм фрізичного виховання. Необхідно спрямувати зацікавленість учнів до занять спортом у системі дитячо-юнацького та масового спорту. Регулярні заняття викликатимуть інтерес і до фізичних вправ на уроках фрізичної культури.

Мета дослідження - вивчити вмотивованість школярів до відвідування уроків фрізичної культури та спортивних секцій і вплив учителів фізичної культури, тренерів та батьків на фрормування інтересу до занять руховою активністю.

Методи дослідження: аналіз літературних джерел та мережі Інтернет, опитування, узагальнення, систематизація, методи математичної статистики.

Результати дослідження та їх обговорення. Дослідження проводили на базі 15 закладів загальної середньої освіти (33С0) м. Івано-Франківськ. У дослідженні брали участь 167 осіб: 36 учителів фрізичної культури 28-67 років (чоловіки та жінки, середній вік 43,7 \pm 0,13 року; педагогічний стаж $15,8 \pm 2,32$ року); 72 учні 5-6-х класів, 45 батьків; 14 тренерів-викладачів ДЮСШ 3 футболу, волейболу, легкої атлетики, веслування на байдарках і каное, таеквондо, баскетболу.

Статистичну обробку даних проводили за допомогою програмного пакета «Statistica 6.0» (StatSoft Inc. США, 1999) і редактора таблиць «Еxcel 2003» (Microsoft, США, 2003). Для обробки даних, отриманих під час проведення досліджень, використовували метод середніх величин, що включав розрахунок середнього значення, стандартного відхилення $[17,18]$.

Опитування вчителів фізичної культури показало, що спостерігається негативна тенденція у відвідуванні спортивних гуртків та секцій в

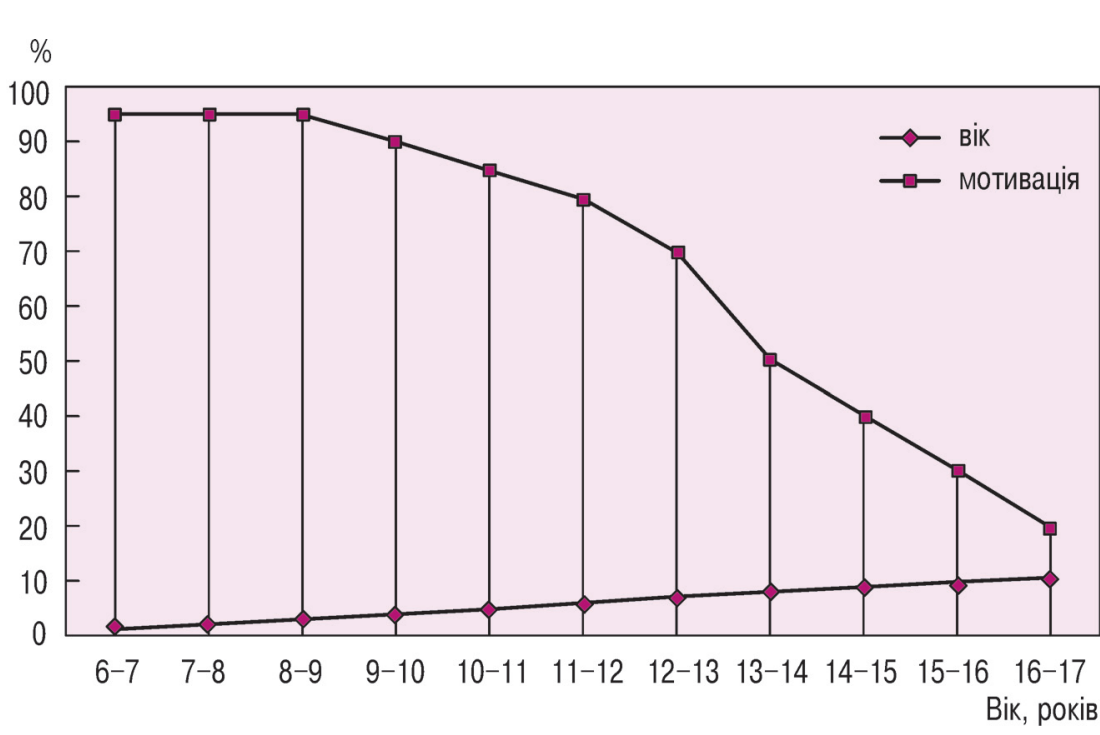

Рисунок 2 - Динаміка зниження мотивації школярів до відвідування уроку фрізичної культури та занять фозичними вправами, $\mathrm{n}=36$ :

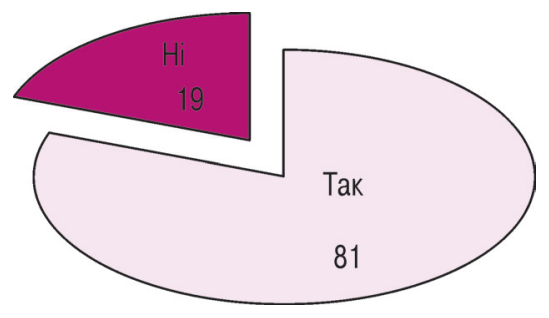

Рисунок 1 - Визначення думок респондентів щодо мотивації до занять фрізичними вправами, $\mathrm{n}=36, \%$

дитячо-юнацьких спортивних школах. Зниження мотивації до уроку фрізичної культури у школярів відмічають 81 \% опитаних вчителів, 19 \% вважають, що учні мають достатній інтерес до уроків та мотивовані до занять фрізичними вправами (рис. 1).

Слід зауважити, що зниження мотивації до уроків фрізичної культури вчителі відмічають в учнів старших, частково середніх класів, починаючи 3 14-16 років (рис. 2). Разом 3 тим, 94 \% учнів відвідували б уроки фрізичної культури за умови їх необов'язковості, 6 \% - не бажають відвідувати

За даними Г. Безверхньої [1], відсутність інтересу та зацікавленості на уроці, змістом уроків фрізичної культури притаманна четвертій частині школярів (20-25 \% хлопців і дівчат).

Відповіді вчителів свідчать, що зниження мотивації до відвідування уроків фізичної культури збігається 3 небажанням відвідувати спортивні секції та гуртки. Опитування учнів се- 
редніх шкіл показало, що тільки п'ята частина (22 \%) учнів 5-6-х класів відвідують спортивні секції, 88 \% - не займаються спортом.

За словами вчителів фізичної культури, які мають стаж роботи у школі понад 20 років, школярі 10 років відвідували одну і більше спортивних секцій. Крім того, на базі школи діяли різноманітні спортивні гуртки, а проводили тренування - вчителі фізичної культури, які працювали в цьому самому закладі й знали учнів. 3 одного боку, ця практика давала змогу залучити велику кількість дітей до занять масовим спортом, а з іншого, з числа школярів здійснювалась підготовка команд для участі в міжшкільних змаганнях і формувалось спортивне ядро для подальшого переходу в систему дитячо-юнацького спорту. Спостерігалася більш тісна співпраця вчителів фрізичної культури та тренерів-викладачів 3 певних видів спорту [9].

За даними опитування, переважна більшість шкіл (63 \%) має в наявності спортивні секції на базі $33 \mathrm{CO}$, проводяться тренування 3 різноманітних видів спорту, зокрема волейболу, баскетболу, фрутболу, таеквондо, кудо, плавання (у школах з басейнами) тощо. Проте заняття проводять тренери зі спортивних клубів та ДЮСШ. У 26 \% шкіл, що брали участь в опитуванні, відсутні будь-які спортивні гуртки та секції, і лише в одній 3 десяти шкіл (11\%) епізодично проводяться позакласні гуртки з видів спорту під керівництвом учителя фрізичної культури (рис. 3). Співпраці між ДЮСШ та 33 СО не спостерігається, взаємодія здійснюється під час вирішення питань оренди спортивного залу. Проведення тренувальних занять у секціях на базі З3СО має свої позитивні сторони: школярі мають можливість спостерігати за тренуваннями, тренери - проводити набір нових учнів з числа вихованців школи.

До чинників, які впливають на формування інтересу до занять фізичною культурою і спортом, відносять: поради батьків, рекомендації вчителя фрізичної культури, знання про користь вправ, ЗМІ, оточуючі та друзі [3]. Значущим чинником у

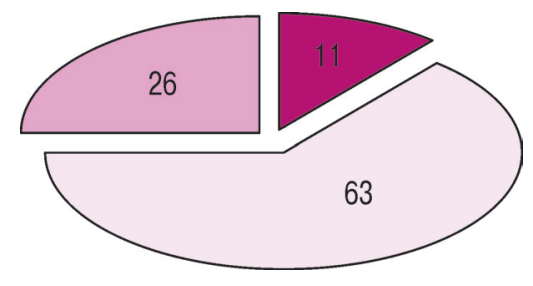

Рисунок 3 - Співвідношення спортивних секцій та гуртків на базі $33 \mathrm{CO}$ м. ІваноФранківськ за результатами опитування, $\mathrm{n}=50, \%$

$\square$ - спортивні гуртки
$\square$ - спортивні секції
$\square$ - відсутні спортивні секції

формуванні інтересу до занять фрізичною культурою і спортом визначено поради батьків та знання про користь вправ.

За результатами опитування, у виборі виду спорту лише 3 \% учнів сприяв учитель фрізичної культури (рис. 4).

Незначній кількості школярів рекомендував конкретну спортивну секцію чи тренера вчитель фізичної культури, 98 \% дітей прийшли до секції за допомогою реклами, батьків, друзів. Такий відсоток вказує на те, що відсутня необхідна зацікавленість 3 боку викладачів загальноосвітніх шкіл у співпраці між тренерським та педагогічним колективом. 26 \% дітей почали займатися спортом 3 ініціативи батьків, 26 \% - почули про секцію від родичів та знайомих, $18 \%$ - завдяки друзям, чи однокласникам, 16 \% школярів - особисто відібрав тренер та 11 \% дітей - почули інфрормацію про

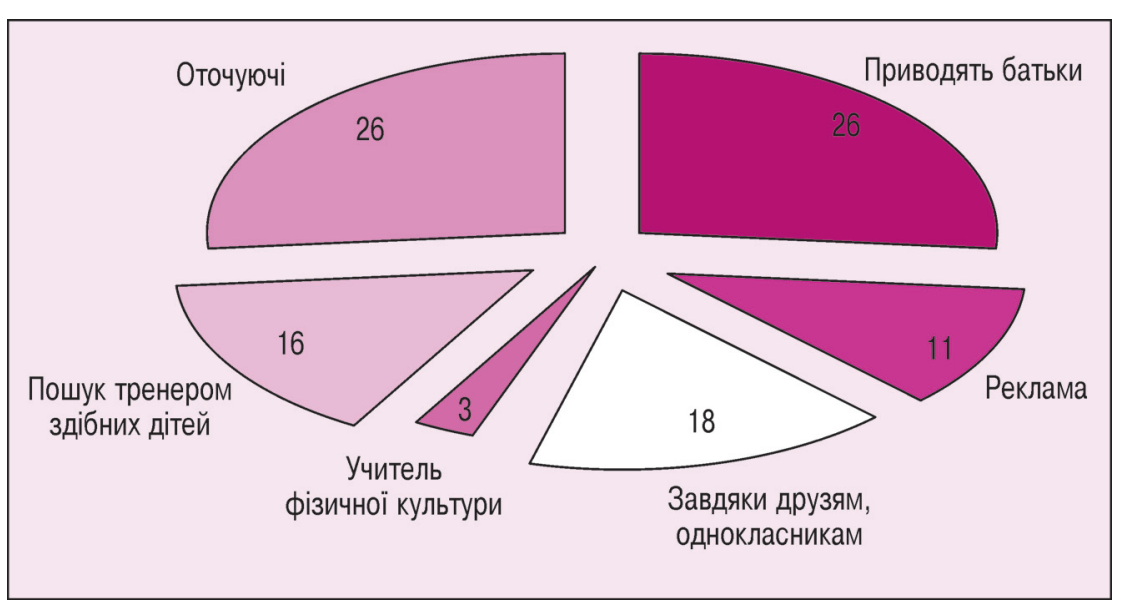

Рисунок 4 - Способи залучення дітей до спортивних секцій м. Івано-Франківськ за результатами опитування тренерів, $\mathrm{n}=14, \%$ рекламу в соціальних мережах.

Більшість вчителів наголошують на тому, що рекомендують учням спортивні секції, сприяють їх залученню в групи початкової спортивної підготовки. На запитання «Чи берете ви участь у відборі здібних дітей до занять певним видом спорту?» $100 \%$ вчителів відповіли ствердно.

Усі опитані вчителі фрізичної культури співпрацюють зі спортивними школами, клубами, окремими тренерами 3 метою залучення школярів у певну спортивну секцію. Ряд вчителів співпрацює з кількома спортивними школами та різними тренерами 3 видів спорту. Вчителі зазначають, що здебільшого надають лише рекомендації дітям щодо вибору виду спорту, рідше беруть особисту участь та дають контакти тренерів, відводять у спортивну школу, здійснюють подальший контроль. Проте тренери виділяють спосіб залучення дітей шляхом уроків фрізичної культури як один з найбільш дієвих $[9,14,15]$.

Значна частка вчителів фрізичної культури (81 \%) відмічають знижений інтерес учнів до занять фізичними вправами та пасивність на уроках фрізичної культури, 78 \% батьків вважають свою дитину активною, яка охоче бере участь у рухливих іграх у дворі чи виявляє щирий інтерес до фізичних вправ, або займається руховою активністю, чи відвідує спортивну секцію; 12 \% - визначили, що скоріше не цікавляться, 4 \% - зовсім не певний вид спорту через 3MI, афріші, 
цікавляться та 6 \% важко відповісти. 72 \% дітей протягом року відвідували один гурток та більше, чи секцію рекреаційно-оздоровчої, спортивної спрямованості.

За результатами опитування батьків виділено види рухової активності школярів 5-6-х класів:

- прогулянки, рухливі ігри надворі з однолітками, велопрогулянки, їзда на роликових ковзанах, самокаті, скейті тощо (активне дозвілля);

- відвідування закладів оздоровчорекреаційного, розважального спрямування: альпінпарків (мотузкових парків), центрів розваг з ігровими 30нами (ролердроми, ігрові лабіринти, боулінг тощо);

- заняття фрітнесом вдома з батьками (сімейне дозвілля);

- заняття срітнесом, танцями, єдиноборствами у фітнес-клубах, танцювальних студіях;

- заняття спортом (секції з видів спорту на базі фрітнес та спортивних клубів, ДЮСШ).

Дискусія. Нами з'ясовано, що до рекомендацій вчителя стосовно змісту рухової активності у вільний час та вибору виду спорту прислухаються лише $3 \%$ учнів, що свідчить про недостатню співпрацю, зацікавлення 3 боку вчителя щодо популяризації занять спортом, знижений авторитет педагога. За даними Г. Безверхньої [2], до порад учителя фрізичної культури прислухається 12,6 \% дівчат та 28,8\% хлопців 6-9-х класів. Цей чинник знаходяться на 3-5-му місцях за значущістю серед учнів, а найсуттєвішим чинником у формуванні інтересу до занять фрізичною культурою і спортом виступають поради батьків та знання про користь вправ.

Учителі фрізичної культури відмічають зниження інтересу учнів як до уроку фрізичної культури, так і до занять спеціально-організованою руховою активністю, особливо в 911-х класах. Це підтверджується даними спеціальної літератури, де зазначається, що з віком збільшується кількість школярів, незадоволених змістом занять (20-25 \% хлопців і дівчат) [1]. Разом з тим, дані опитування свідчать про позитивне ставлення учнів до уроків фрізичної куль- тури: $94 \%$ позитивне і $6 \%$ - ні. 18-27 \% хлопців і дівчат не задоволені змістом уроків фрізичного виховання. Відсутність зацікавленості на уроках, відповідно і змісту уроків фрізичної культури, характерна для 20-25 \% школярів [2]. Однією 3 причин незадоволеності змістом уроку фрізичної культури, як зазначають дослідники [6], виступає неврахування потребово-мотиваційних пріоритетів учнів у виборі засобів фрізичної культури. Від 16 до 56 \% школярів 6-9-х класів стверджують, що вчителі не проводять опитування про види спорту та форми їх проведення на уроці фрізичної культури.

Дослідження показали неузгодженість відповідей учителів, батьків та учнів про мотивацію до занять фрізичною культурою і спортом. Так, учителі констатують зниження мотивації до уроків фрізичної культури, проте учні та батьки відмічають присутність інтересу підлітків до фрізичних вправ та відвідування різних спортивнорекреаційних і оздоровчих заходів Батьки вважають своїх дітей активними, як ті, що відвідують різні спортивні секції. Проте заняття не є регулярними. Це підтверджується даними 0. Жданової [4], яка зазначає, що спільні заняття 3 фрізичної культури батьків із дітьми в основному обмежуються лише фрізичними вправами під час відпочинку. Розбіжність у відповідях батьків і дітей свідчить про недостатність їх контактів [1]. Невідповідність у відповідях респондентів може свідчити про певну необізнаність, непоінформованість учителів про спосіб життя вихованців за межами навчального закладу Залишається невирішеним питання щодо організації та проведення вчителем фрізичної культури секційних занять на базі школи. Вони здійснюють це на громадських засадах 3 метою підготовки шкільної команди до змагань. Наші дослідження та думки інших науковців збігаються на необхідності формування дієвого механізму організації рухової активності школярів та підвищення їх мотивації до них шляхом урахування інтересів школярів у навчальний та позанавчальний час, налагодження співпраці 33С0 зі спортивними клубами,
ДЮСШ, визначення чітких критеріїв оцінювання мотивації до занять фрізичною культурою та різними видами рухової активності та заходів з її підвищення.

Висновки. За даними проведених досліджень встановлено, що вчителі фрізичної культури спостерігають зниження інтересу школярів до занять фрізичними вправами, пасивність на уроках, відвідування обов'язкових форм фрізичної культури в 33С0, що впливає на відвідування спортивних секцій.

Дані опитування школярів свідчать про їх бажання відвідувати уроки фрізичної культури, займатися руховою активністю в різних спортивних секціях та клубах. 72 \% дітей протягом року відвідували спортивні секції та гуртки рекреаційно-оздоровчої, спортивної спрямованості. Батьки підтримують дітей у заняттях руховою активністю, про що свідчать результати опитування (78 \%). Більшість батьків самостійно організовують дозвілля дітей засобами фрізичної рекреації та спорту в домашніх умовах, під час прогулянок, залучають їх до епізодичних занять оздоровчо-рекреаційного характеру.

У місті 63 \% шкіл мають спортивні секції, проте тільки 11 \% вчителів задіяні в роботі таких секцій. Відзначено зацікавленість дітей та батьків у проведенні спортивних заходів та секцій на базі школи саме вчителями фрізичної культури. Спостерігається низька взаємодія вчителів фрізичної культури та тренерів з видів спорту у використанні спортивної бази З3СО та залучення здібних дітей у групи початкової спортивної підготовки у ДЮСШ.

Перспективи подальших досліджень полягають у визначенні шляхів активізації дітей у відвідуванні спортивних секцій та умови співпраці закладів середньої освіти та дитячоюнацьких шкіл із залучення здібних дітей до занять спортом.

Конфлікт інтересів. Автор заявляє, що відсутній будь-який конфллікт інтересів.

\section{ЛITEPATУPA}

1. Безверхня ГВ. Мотивація до занять фрізичною культурою і спортом школярів 5-11 класів [автореферат]. Львів: ЛДІФК; 2004. 23 с. 
2. Безверхня ГВ, Цибульська ВВ, Гончар ГІ. Мотивація до занять фізичною культу рою і спортом школярів та студентів [монографія]. Умань: ВПЦ «Візаві»;2016. 223 с.

3. Бойко 0. Теоретичні аспекти впливу мотиваційних складових на підвищення ефективності занять із фрізичної культури Фізичне виховання, спорт і культура здоров'я у сучасному суспільстві: зб. наук. праць. 1 (21) 2013. 94-98.

4. Жданова 0, Шевців У. Вплив сім’ї на мотивацію підлітків до занять фізичною культурою. Молода спортивна наука України. 2015 2: $91-5$

5. Круцевич ТЮ. Концепция системы физического воспитания в общеобразовательных школах. Теорія і методика фізичного виховання і спорту. 2015; 2: 72-80.

6. Круцевич Т, Іщенко 0, Імас Т. Мотивація учнів 6-9 класів до уроків фізичної культури. Спортивний вісник Придніпров'я. 2014; 2: 68-72.

7. Остапенко 0. Виховання в учнів 8-9 класів інтересу до занять фізичною культурою. Фізичне виховання в школі. 2002; 2: 19-23.

8. Офріційний сайт В003 [Електронний ресурс]. Режим доступу: http://www.who.int

9. Шинкарук 0. Узагальнення досвіду організації відбору в олімпійському спорті Теорія і методика фізичного виховання і спорту. 2001: 2-3; 35

10. Шинкарук 0. Особливості організації відбору спортсменів у циклічних видах спорту. Теорія і методика фрізичного виховання і спорту. 2002: $1 ; 34-42$

11. Шинкарук ОА. Обґрунтування викори стання фізіологічних показників як критеріїв відбору спортсменів у циклічних видах спорту. Актуальні проблеми фізичної культури і спорту: 3б. наук. праць. 2004; 3: 52-5

12. Шинкарук ОА. Формування погляду на розвиток дитячо-юнацького спорту шляхом аналізу діяльності спортивних шкіл за 19962003 рр. Теорія і методика фрізичного виховання і спорту. 2004; 2: 65-69.

13. Шинкарук 0. Особливості олімпійськой підготовки спортсменів у зарубіжних країнах Фізичне виховання, спорт і культура здоров'я у сучасному суспільстві: зб. наук. праць. Луцьк. 2012: 1 (17); 126-9.

14. Шинкарук 0. Система відбору та орієнтації в різних країнах світу. Спортивний вісник Придніпров'я. 2014; 1: 191-8

15. Шинкарук 0, Мітова 0. Система контролю підготовки початківців у командних спортивних іграх: проблемні питання та сучасні підходи. Спортивний вісник Придніпров'я. 2017; 1: $105-112$

16. Ярова ОБ. Фізкультурна освіта і спорт у початковій школі Євросоюзу: сучасний стан і тенденції розвитку. Педагогічні науки: теорія історія, інноваційні технології. № 4.401-412. Режим доступу: http://nbuv.gov.ua/UJRN/ pednauk_2014_450

17. Byshevets N, Shynkaruk 0, Stepanenko 0 , Gerasymenko S, Tkachenko S, Synihovets I, Filipov V., Serhiyenko K, lakovenko 0. Development skills implementation of analysis of variance at sport-pedagogical and biomedical researches. Physical Education and Sport, 2019; 19 (6) Art 311, pp 2086 - 2090, 2019. DOI:10.7752 jpes.2019.s6311

18. Byshevets N, Denysova L, Shynkaruk 0, Serhiyenko K, Usychenko V, Stepanenko 0, Syvash I. Using the methods of mathematical statistics in sports and educational research. Journal of Physical Education and Sport, 2019; 19 (3), Art 148, pp 1030-4. D0I:10.7752/jpes.2019.s3148

19. Global Strategy on Diet, Physical Activity and Health. [Електронний ресурс]. Режим до- ступу: https://www.who.int/dietphysicalactivity/ factsheet_young_people/en/

20. Tretiak 0, Danylo S, Konovalska $L$, Bazylchuk 0, Sushchenko L, Bazylchuk V, Shynkaruk 0, Denysova L. Factor structure of interrelation between indices of physical condition and definition of the level of physical readiness of future specialists in higher pedagogical education to act in extreme situations. Journal of Physical Education and Sport,2020; 20 (1), Art 68 pp. 461 468. DOI:10.7752/jpes.2020.s1068

21. World Health Organization Regional Office for Europe physical activity facts heets for the 28 European Union member states of the who European region (2018). World Health Organization. [Електронний ресурс]. Режим доступу: https://ec.europa.eu files'physical-activityfactsheet_who-eu-201811_en

\section{LITERATURE}

1. Bezverkhnia HV. Motivation of $5-11$ grade pupils to practicing physical culture and sport [author's abstract. Lviv: LDIPC; 2004. 23 p.

2. Bezverkhnia HV, Tsybulska VV, Honcha HI. Motivation of school children and students to practicing physical culture and sport [monograph] Uman: VPTS «Vizavi»;2016. 223 p.

3. Boyko 0. Theoretical aspects of the influence of motivational components on improving the effectiveness of physical education classes.Fizychne vykhovannia, sport i kultura zdorovia u suchasnomu suspilstvi: зб. наук. праць. 1 (21); 2013. 94-98

4. Zhdanova 0, Shevtsiv U. Family impact on teenagers' motivation to physical culture engagement. Moloda sportyvna nauka Ukrainy. 2015; 2 91-5

5. Krutsevich TY. Concept of physical education system at secondary schools. Teoriia i metodyka fizvykhovannia i sportu. 2015; 2: 72-80.

6. Krutsevych T, Ishchenko 0, Imas T. Motivation of 6-9 grade pupils to physical culture lessons Sportyvnyi visnyk Prydniprovia. 2014; 2: 68-72.

7. Ostapenko 0 . Ecouraging pupils of the $8-9$ grades to practicing physical culture. Fizvykhovania v shkoli. 2002; 2: 19-23.

8. Official site of the WHO [Electronic re source]. Access mode: http://www.who.int

9. Shynkaruk 0. Generalization of selection organization experience in the Olympic sport. Teoriia i metodyka fizvykhovannia i sportu 2001: 2-3; 35

10. Shynkaruk 00. Peculiarities of athlete selection organization in cyclic sports events. Teoriia i metodyka fizvykhovannia i sportu. 2002 $1 ; 34-42$

11. Shynkaruk $O A$. Substantiating the use of physiological indices as criteria of athletes' selection in cyclic sports events. Aktualni problem fizkultury i sportu : zb. nauk. prats. 2004; 3: 52-5.

\section{ІНФОРМАЦІЯ ПРО АВТОРА}

Матвієнко Ірина Сергіївна https://orcid.org/0000-0002-2355-5776, e-mailirina.matvienko8@ gmail.com

Національний університет фрізичного виховання і спорту України,

03150, Київ, вул. Фізкультури, 1

НУФВСУ, Івано-Франківський коледж ффізичного виховання НУФВСУ

\section{INFORMATION ABOUT THE AUTHOR}

Matvienko Irina https://orcid.org/0000-0002-2355-5776, e-mailirina.matvienko8@gmail.com National University of Ukraine on Physical Education and Sport,

03150, Kyiv, Fizkul'tury str., 1.

Ivano-Frankivsk College of Physical Culture of the National University of Ukraine of Physica Education and Sport, Ukraine 